\title{
FAKTOR-FAKTOR YANG BERHUBUNGAN DENGAN KEJADIAN DISMENOREA PADA SISWI SMAN 1 LOLAK
}

\author{
St. Rahmawati Hamzah ${ }^{1}$, Hamzah $B^{2}$ \\ Fakultas Ilmu Kesehatan, Institut Kesehatan dan Teknologi Graha Medika ${ }^{1,2}$ \\ rahmahamzah94@gmail.com ${ }^{1}$, hamzahbskm@gmail.com²
}

\begin{abstract}
Data from the World Health Organization shows that the incidence of dysmenorrhea is quite high throughout the world. The average incidence of dysmenorrhea in young women is between 16,8\%-81\%. The prevalence of adolescent girls in Indonesia who experience dysmenorrhea is $64,25 \%$ consisting of $54,89 \%$ primary dysmenorrhea and 9,36\% secondary dysmenorrhea. The purpose of this study was to analyze the factors associated with the incidence of dysmenorrhea in SMA Negeri 1 Lolak. This study used an analytic observational design with a cross sectional design with a sample size of 68 respondents. The sampling technique used was total sampling. Data for each variable was collected using a questionnaire through interviews and then the data was then analyzed by univariate and bivariate with chi square test. The results of research conducted at SMAN 1 Lolak showed that there was a relationship between the age of menarche and the incidence of dysmenorrhea in female students $(p=0,030<0,05)$, there was a relationship between family history and the incidence of dysmenorrhea in female students $(p=0,039<0,05)$, and there was the relationship between exercise habits and the incidence of dysmenorrhea in female students ( $p=0,024<0,05)$. The conclusion of this study shows that the factors associated with the incidence of dysmenorrhea in class XI students of SMA Negeri 1 Lolak are age of menarche, family history and exercise habits. So it is necessary to do concrete prevention efforts to minimize the incidence of dysmenorrhea in adolescent girls.
\end{abstract}

Keywords $\quad$ : Dysmenorrhea, Menarche, Students

\begin{abstract}
ABSTRAK
Data World Health Organization menunjukkan angka kejadian dismenorea cukup tinggi di seluruh dunia. Rata-rata insiden terjadinya dismenorea pada wanita muda antara 16,8\%-81\%. Pevelensi remaja putri di Indonesia yang mengalami dismenorea yaitu $64,25 \%$ yang terdiri dari dismenorea primer $54,89 \%$ dan dismenorea sekunder 9,36\%. Tujuan penelitian ini untuk menganalisis faktor yang berhubungan dengan kejadian dismenorea di SMA Negeri 1 Lolak. Penelitian ini menggunakan desain observasional analitik dengan rancangan cross sectional dengan jumlah sampel 68 responden. Teknik penarikan sampel menggunakan total sampling. Data setiap variabel dikumpulkan menggunakan kuesioner melalui wawancara kemudian data selanjutnya dianalisis secara univariat dan bivariat dengan uji chi square. Hasil penelitian yang dilakukan di SMAN 1 Lolak menunjukkan bahwa ada hubungan usia menarche dengan kejadian dismenorea pada siswi $(\mathrm{p}=0,030<0,05)$, ada hubungan riwayat keluarga dengan kejadian dismenorea pada siswi $(\mathrm{p}=0,039<0,05)$, dan ada hubungan kebiasaan olahraga dengan kejadian dismenorea pada siswi $(\mathrm{p}=0,024<0,05)$. Kesimpulan hasil penelitian ini menunjukkan bahwa faktor-faktor yang berhubungan dengan kejadian dismenorea pada siswi kelas XI SMA Negeri 1 Lolak adalah usia menarche, riwayat keluarga dan kebiasaan olahraga. Sehingga perlu dilakukan upaya pencegahan yang konkrit untuk meminimalisir kejadian dismenorea pada remaja putri.
\end{abstract}

Kata Kunci : Dismenorea, Menarche, Siswi 


\section{ISSN 2623-1573 (Print)}

\section{PENDAHULUAN}

Menurut World Health Organization (WHO) angka kejadian dismenorea cukup tinggi di seluruh dunia. Rata-rata insiden terjadinya dismenorea pada wanita muda antara $16,8 \%$ sampai $81 \%$. Rata-rata di negara Eropa kejadian dismenorea terjadi pada $45 \%$ sampai $97 \%$ wanita, dengan prevelensi terendah di Bulgaria 8,8\% dan tertinggi di Finlandia mencapai $94 \%$. Beberapa studi epidemiologi dibeberapa negara seperi Mesir didapatkan 71,6\% wanita mengalamai dismenorea dengan tingkatan yang berbeda, di India ditermukan prevalensi dismenorea sebesar 73,83\% (Utami et al., 2013).

Remaja putri di Indonesia yang sudah mengalami haid rata-rata telah mengalami menarche pada usia 13 tahun $(20,0 \%)$ dengan kejadian lebih awal kurang dari 9 tahun dan ada yang lebih lambat sampai umur 20 tahun. Secara nasional rata-rata usia menarche 13-14 tahun terjadi pada 37,5\% remaja putri di Indonesia (Adriani, 2018). Menurut Kemenkes RI tahun (2016) prevelensi remaja putri di Indonesia yang mengalami dismenorea yaitu sebesar $64,25 \%$ yang terdiri dari dismenorea primer $54,89 \%$ dan dismenorea sekunder $9,36 \%$ (Wulanda et al., 2020).

Menurut Prayitno (2014) dismenorea atau nyeri haid merupakan suatu keluhan ginekologis yang diakibatkan ketidakseimbangan hormon progesteron dalam darah sehingga mengakibatkan timbulnya rasa nyeri yang paling sering dialami oleh wanita (Payitno, 2014). Remaja putri usia sekolah yang mengalami nyeri haid atau dismenorea akan mengakibatkan susah untuk konsentrasi dalam belajar mengajar dan meningkatkan peluang ketidakhadiran di sekolah. Ketidaknyamanan yang ditimbukan dari gangguan nyeri menstruasi harus segera ditangani agar tidak menimbulkan dampak kesehatan yang serius (Nirwana, 2011).
Berdasarkan data Badan Pusat Statistik Sulawesi Utara tahun 2017 jumlah remaja putri di Sulawesi Utara yaitu berjumlah $36,167 \%$ jiwa (BPS Sulut, 2017). Pada tahun 2020, prevelensi dismenorea di Sulawesi Utara mencapai sebesar 98,5\% dengan keluhan $10,1 \%$ mengalami muntah, $14,1 \%$ nyeri kepala, 33,7\% gangguan emosi dan $1 \%$ pingsan (Ponda \& Belung, 2018). Dismenorea primer sering terjadi, kemungkinan lebih dari 50\% wanita mengalaminya dan $15 \%$ diantaranya mengalami nyeri pada saat menstruasi yang hebat. Biasanya dismenorea timbul pada masa remaja, yaitu sekitar 2 sampai 3 tahun setelah menstruasi pertama (Sukarni \& Margareth, 2013).

Remaja yang mengalami dismenorea primer sering merasakan tidak nyaman saat haid, hal ini dikarenakan rasa nyeri yang dialami pada bagian perut bawah sehingga sulit dalam beraktivitas sehari-hari. Kejadian dismenorea primer dapat mempengaruhi kualitas hidup produktivitas dan pemanfaatan layanan kesehatan selama masa reproduksi wanita (Sakinah \& Ekayanti, 2016). Dampak dari dismenorea bila dibiarkan dan tidak ditangani dapat menyebabkan bahaya nyeri yang hebat sehingga bisa menyebabkan endometriosis atau kemandulan (Prawiroharjo, 2020). Remaja putri dengan usia menarche dibawah 12 tahun memiliki risiko $23 \%$ lebih tinggi mengalami dismenorea dibandingkan dengan remaja putri dengan usia menarche 12-14 tahun. (Larasati \& Alatas, 2016).

Penyebab kejadian dismenorea pada remaja putri dapat disebabkan oleh penyebab langsung dan penyebab tidak langsung. Penyebab langsung meliputi faktor endoktrin dan faktor miometrium sedangkan penyebab tidak langsung seperti usia menarche, riwayat keluarga dan kebiasaan olahraga. Penelitian yang dilakukan di SMK Sasmita Jaya 1 Pamulang menunjukkan terdapat hubungan usia menarche dengan dismenorea 
(Romlah \& Agustin, 2021). Hasil penelitian pada wanita usia subur di Kelurahan Ploso menunjukkan bahwa ada hubungan antara riwayat keluarga dengan terjadinya dismenorea primer, hal ini menunjukkan ada tidaknya anggota keluarga sedarah yang mengalami dismenorea primer mempunyai kontribusi untuk terjadinya dismenorea primer (Ammar, 2016). Penelitian lain yang dilakukan remaja putri di Komonitas Senam Aerobik Mojokerto menunjukkan kebiasaan olahraga yang dilakukan derajat kesehatan lambat laun menjadi lebih baik, mereka menyatakan derajat nyeri saat haid sebelum dan sesudah juga nampak ada perubahan. Setelah mengikuti senam nyeri haid yang dirasakan responden dirasa berkurang dan ada responden yang menyatakan hilang sama sekali (Kusmindarti \& Munadlifah, 2016).

Berdasarkan studi pendahuluan yang dilakukan pada siswi kelas XI SMA Negeri 1 Lolak, terdapat 17 dari 22 siswi kelas XI menyatakan mengalami dismenorea saat menstruasi. Menurut siswi yang dirasakan saat dismenorea adalah nyeri berupa keram perut, terasa pusing, mudah lelah, lemas sehingga aktivitas belajar mengajar menjadi terganggu bahkan ada 7 siswi sampai tidak masuk sekolah saat mengalami dismenorea. Dari permasalahan diatas maka peneliti tertarik untuk melakukan penelitian tentang faktor-faktor yang berhubungan dengan kejadian dismenorea pada siswi kelas XI SMA Negeri 1 Lolak. Adapun tujuan penelitian ini adalah untuk menganalisis hubungan usia menarche, riwayat keluarga, dan kebiasaan olahraga dengan kejadian dismenorea pada siswi kelas XI SMA Negeri 1 Lolak.

\section{METODE}

Jenis penelitian yang digunakan yaitu survei observasional analitik dengan pendekatan cross sectional study, yaitu suatu studi epidemiologi dimana pengukuran hubungan antara variabel independen (usia menarche, riwayat keluarga dan kebiasaan olahraga) dengan variabel dependen (kejadian dismenorea) dilakukan pada saat yang bersamaan. Penelitian ini dilakukan di SMA Negeri 1 Lolak Kabupaten Bolaang Mongondow pada bulan April sampai Mei 2021. Populasi penelitian ini adalah seluruh siswi kelas XI SMA Negeri 1 Lolak berjumlah 68 siswi. Sampel adalah sebagian dari populasi yang menjadi unit analisis maka jumlah sampel pada penelitian ini adalah 68 responden sehingga teknik penarikan sampel yang digunakan adalah total sampling, yaitu teknik penarikan sampel dimana jumlah sampel sama dengan populasi. Alasan pemilihan total sampling adalah karena jumlah populasi kurang dari 100 (Sugiyono, 2017).

Data diperoleh dari data primer dan data sekuender. Data primer dikumpulkan menggunakan kuesioner melalui wawancara dan data sekunder diperoleh dari data Dapodik SMA Negeri 1 Lolak. Data yang sudah dikumpulkan diolah melalui tahapan editing, coding, entry, tabulating dan cleaning, kemudian data dianalisis secara univariat untuk memberikan gambaran terkait variabel penelitian dan bivariat untuk menganalisis hubungan variabel penelitian dengan menggunakan uji chi square $\alpha=0,05$.

\section{HASIL}

Tabel 1. Distribusi Frekuensi Berdasarkan Usia Menarche, Riwayat Keluarga, dan Kebiasaan Olahraga pada Siswi di SMA Negeri 1 Lolak

\begin{tabular}{|c|c|c|}
\hline Variabel Penelitian & Frekuensi & $\%$ \\
\hline \multicolumn{3}{|l|}{ Usia Menarche } \\
\hline$\geq 12$ Tahun & 17 & 25,0 \\
\hline$<12$ Tahun & 51 & 75,0 \\
\hline \multicolumn{3}{|l|}{ Riwayat Keluarga } \\
\hline Ada & 56 & 82,4 \\
\hline Tidak Ada & 12 & 17,6 \\
\hline \multicolumn{3}{|l|}{ Kebiasaan Olahraga } \\
\hline Jarang & 57 & 83,8 \\
\hline Sering & 11 & 16,2 \\
\hline Total & 68 & 100 \\
\hline
\end{tabular}




\section{ISSN 2623-1573 (Print)}

Tabel 1 di atas menunjukkan bahwa responden dengan usia menarche $<12$ tahun sebanyak 51 (75\%) sedangkan usia menarche $\geq 12$ tahun sebanyak 17 (25\%). Responden yang menyatakan ada riwayat keluarga sebanyak $56 \quad(82,4 \%)$ sedangkan yang menyatakan tidak ada riwayat keluarga sebanyak 12 (17,6\%). Dan responden yang jarang melakukan olahraga sebanyak 57 $(83,8 \%)$ sedangkan yang sering melakukan olahraga sebanyak $11(16,2 \%)$.

Tabel 2 di bawah menunjukkan bahwa distribusi responden yang mengalami kejadian dismenorea pada siswi SMA Negeri 1 Lolak sebanyan 60 responden $(88,2 \%)$ sedangkan yang tidak mengalami dismenorea sebanyak 8 responden $(11,8 \%)$.

Tabel 2. Distribusi Frekuensi Kejadian Dismenorea pada Siswi di SMA Negeri 1 Lolak

Kejadian Dismenorea

\begin{tabular}{lcc}
\hline $\begin{array}{l}\text { Dismenorea } \\
\text { Tidak } \\
\text { Dismenorea }\end{array}$ & 60 & 88,2 \\
\hline \multicolumn{1}{c}{ Total } & 8 & 11,8 \\
\hline
\end{tabular}

Tabel 3. Hubungan Usia Menarche dengan Kejadian Dismenorea pada Siswi SMA Negeri 1 Lolak Kejadian Dismenorea

\begin{tabular}{|c|c|c|c|c|c|c|c|}
\hline \multirow{3}{*}{ Usia Menarche } & \multirow{2}{*}{\multicolumn{2}{|c|}{ Dismenorea }} & \multirow{2}{*}{\multicolumn{2}{|c|}{ Tidak Dismenorea }} & \multirow{2}{*}{\multicolumn{2}{|c|}{ Total }} & \multirow{3}{*}{$p$-value } \\
\hline & & & & & & & \\
\hline & $\mathbf{n}$ & $\%$ & $\mathbf{n}$ & $\%$ & n & $\%$ & \\
\hline$\geq 12$ Tahun & 12 & 70,6 & 5 & 29,4 & 17 & 100 & \\
\hline$<12$ Tahun & 48 & 94,1 & 3 & 5,9 & 51 & 100 & 0,030 \\
\hline Total & 60 & 44,6 & 8 & 11,8 & 68 & 100 & \\
\hline
\end{tabular}

Tabel 3 di atas menunjukkan bahwa dari 17 responden yang mempunyai usia menarche $\geq 12$ tahun terdapat $12(70,6 \%)$ responden yang menderita dismenorea dan terdapat $5(29,4 \%)$ responden yang tidak menderita dismenorea, sedangkan dari 51 responden yang mempunyai usia menarche $<12$ tahun terdapat $3(5,9 \%)$ responden yang tidak menderita dismenorea, dan terdapat 48 $(94,1 \%)$ responden yang menderita dismenorea.

Berdasaran hasil analisis statistik dengan menggunakan uji chi-square maka didapatkan nilai $p$ value $=0,030<0,05$, maka

Tabel 4. Hubungan Riwayat Keluarga dengan Kejadian Dismenorea pada Siswi SMA Negeri 1 Lolak

\begin{tabular}{|c|c|c|c|c|c|c|c|}
\hline \multirow{3}{*}{$\begin{array}{c}\text { Riwayat } \\
\text { Keluarga }\end{array}$} & \multicolumn{4}{|c|}{ Kejadian Dismenorea } & \multirow{2}{*}{\multicolumn{2}{|c|}{ Total }} & \multirow{3}{*}{$p$-value } \\
\hline & \multicolumn{2}{|c|}{ Dismenorea } & \multicolumn{2}{|c|}{ Tidak Dismenorea } & & & \\
\hline & $\mathbf{n}$ & $\%$ & $\mathbf{n}$ & $\%$ & $\mathbf{n}$ & $\%$ & \\
\hline Ada & 52 & 92,9 & 4 & 7,1 & 56 & 100 & \\
\hline Tidak Ada & 8 & 66,7 & 4 & 33,3 & 12 & 100 & 0,039 \\
\hline Total & 60 & 88,2 & 8 & 11,8 & 68 & 100 & \\
\hline
\end{tabular}

didapatkan ada hubungan antara usia menarche dengan kejadian dismenorea pada Siswi SMA Negeri 1 Lolak tahun 2021.

Tabel 4 di bawah menunjukkan bahwa dari 56 responden yang memiliki riwayat keluarga terdapat $52(92,9 \%)$ responden yang menderita dismenorea dan terdapat $4(7,1 \%)$ responden yang tidak menderita dismenorea, sedangkan dari 12 responden yang tidak memiliki riwayat keluarga terdapat $4(33,3 \%)$ responden yang tidak menderita dismenorea dan $8(88,2 \%)$ responden yang menderita dismenorea. 
Berdasarkan hasil analisis statistik dengan menggunakan uji chi-square dimana didapatkan nilai $p$ value $=0,039<0,05$, maka didapatkan ada hubungan antara riwayat keluarga dengan kejadian dismenorea pada siswi SMA Negeri 1 Lolak tahun 2021.

Tabel 5. Hubungan Kebiasaan Olahraga dengan Kejadian Dismenorea pada Siswi SMA Negeri 1 Lolak

\begin{tabular}{|c|c|c|c|c|c|c|c|}
\hline \multirow{3}{*}{$\begin{array}{c}\text { Kebiasaan } \\
\text { Olahraga }\end{array}$} & \multicolumn{4}{|c|}{ Kejadian Dismenorea } & \multirow{2}{*}{\multicolumn{2}{|c|}{ Total }} & \multirow{3}{*}{ p-value } \\
\hline & \multicolumn{2}{|c|}{ Dismenorea } & \multicolumn{2}{|c|}{ Tidak Dismenorea } & & & \\
\hline & $\mathbf{n}$ & $\%$ & $\mathbf{n}$ & $\%$ & $\mathbf{n}$ & $\%$ & \\
\hline Jarang & 53 & 93,0 & 4 & 7,0 & 57 & 100 & \\
\hline Sering & 7 & 63,6 & 4 & 36,4 & 11 & 100 & 0,024 \\
\hline Total & 60 & 88,2 & 8 & 11,8 & 68 & 100 & \\
\hline
\end{tabular}

Tabel 5 di atas menunjukkan bahwa dari 11 responden yang sering berolahraga terdapat $7(63,6 \%)$ responden yang menderita dismenorea dan terdapat $4(36,4 \%)$ responden yang tidak menderita dismenorea, sedangkan dari 57 responden yang jarang berolahraga terdapat $4(7,0 \%)$ responden yang tidak menderita dismenorea dan 53 $(93,0 \%)$ responden yang menderita dismenorea.

Berdasarkan hasil analisis statistik dengan menggunakan uji chi-square bahwa yang di peroleh nila $p$ value $=0,024<0,05$, maka didapatkan ada hubungan antara kebiasaan olahraga dengan kejadian dismenorea pada siswi SMA Negeri 1 Lolak tahun 2021.

\section{PEMBAHASAN}

\section{Hubungan Usia Menarche dengan Kejadian Dismenorea pada Siswi}

Usia menarche menjadi salah satu faktor terjadinya kejadian dismenore yang dialami wanita saat menstruasi. Usia menarche yang terjadi pada usia <12 tahun merupakan usia menarche yang tergolong dini atau cepat, sedangkan usia menarche pada usia 12-15 tahun tergolong normal atau. Remaja yang mengalami menstruasi dini (premature) disebabkan oleh faktor internal karena ketidakseimbangan hormon bawaan lahir, hal ini juga berkorelasi dengan faktor ekstrenal seperti asupan gizi pada makanan yang dikonsumsi.

Hasil temuan Shanon (2006) dalam Anwar dan Rosdiana (2016) menunjukkan bahwa semakin cepat menstruasi terjadi menyebabkan kontraksi uterus yang terus menerus sehingga menyebabkan ketersediaan darah ke uterus berhenti sementara sehingga terjadilah dismenorea (Anwar \& Rosdiana, 2019). Temuan di lapangan menunjukkan dari 51 responden dengan usia menarche $<12$ tahun terdapat 48 $(94,1 \%)$ responden yang mengalami dismenorea, hal ini dapat terjadi karena semakin dini seseorang menstruasi maka menyebabkan semakin lama menstruasi terjadi, maka semakin sering uterus berkontraksi akibatnya semakin banyak pula prostaglandin yang diproduksi. Akibat dari produksi prostaglandin yang berlebihan akan menimbulkan rasa nyeri yang hebat saat menstruasi. Hasil uji statistik diperoleh $p$ value $=0,030<0,05$, sehingga terdapat hubungan antara usia menarche dengan kejadian dismenorea pada Siswi SMA Negeri 1 Lolak tahun 2021.

Hasil penelitian ini sejalan dengan penelitian yang dilakukan pada siswi MTS Maarif NU Al Hidayah Banyumas dengan sampel sebanyak 118 responden (59 kelompok kasus dan 59 kelompok kontrol) menemukan bahwa terdapat hubungan usia 


\section{ISSN 2623-1573 (Print)}

menarche dan kejadian disminore primer", dengan OR 3,360 dengan usia menarche $\leq 11$ memiliki risiko 3,4 kali lebih besar mengalami disminore primer dibandingkan usia menarche $>11$ tahun (Soesilowati \& Annisa, 2017). Penelitian lain yang dilakukan pada remaja putri SMK Tanggerang dengan jumlah sampel sebanyak 32 responden, menemukan bahwa terdapat hubungan usia menarche dengan dismenorea pada remaja putri $\mathrm{OR}=23,333$. Hasil ini menunjukkan bahwa remaja putri dengan usia menarche $<12$ tahun berpeluang 23.333 kali mengalami dismenorea dibandingkan dengan remaja putri usia menarche $\geq 12$ tahun (Lail, 2019).

Penelitian serupa yang dilakukan pada mahasiswi tingkat I Akademi Kebidanan RSPAD Gatot Soebroto dengan jumlah sampel sebanyak 59 responden, menemukan bahwa rentan usia menarche 11-13 tahun dengan kejadian disminore mayoritas pada kategori sering sebanyak 10 responden dan terdapat hubungan antara usia menarche dengan terjadinya dismenore pada mahasiswa tingkat I semester II dengan nilai $p$ value 0,002 < 0,05 (Jayanti, 2021). Dan Penelitian yang dilakukan pada siswi kelas X dan XI SMAN 2 Bangkinang Kota dengan jumlah sampel sebanyak 80 responden, menemukan bahwa dari 44 siswi $(55 \%)$ untuk umur menarche terlalu dini $(<12$ tahun), terdapat 11 siswi $(42,4 \%)$ dengan dismenore sehingga ada hubungan umur menarche dengan kejadian dismenore di SMAN 2 Bangkinang Kota (Syafriani, 2021).

Jumlah siswi dengan usia menarche dini $(<12$ tahun) yang cukup banyak dapat disebabkan oleh meningkatnya standar kehidupan terutama faktor asupan makanan yang mengakibatkan pilihan makanan cenderung rendah serat dan tinggi lemak berdampak pada usia menarche dini (Susanti \& Sunarto, 2012). Sebagian besar remaja yang mengkonsumsi lemak berlebih cenderung memiliki asupan serat yang rendah. Konsumsi lemak berlebih tersebut akan dijadikan sebagai simpanan lemak dalam tubuh. Sama halnya jika mengkonsumsi rendah serat, maka akan berdampak pada rendahnya jumlah kolesterol yang mampu dikeluarkan oleh tubuh.

\section{Hubungan Riwayat Keluarga dengan Kejadiam Dismenorea pada Siswi}

Riwayat keluarga merupakan faktor risiko yang dapat meningkatkan terjadinya dismenorea. Dua dari tiga wanita yang menderita dismenorea mempunyai riwayat dismenorea pada keluarganya (Handayani \& Rahayu, 2014). Riwayat keluarga dan risiko dismenore bisa dimungkinkan karena pola hidup maupun gaya hidup yang sama dalam keluarga, jadi meskipun ada riwayat keluarga dengan dismenore tetapi mempunyai gaya dan pola hidup yang berbeda maka bisa menurunkan risiko kejadian tersebut (Tavallaee et al., 2011).

Riwayat dismenorea pada keluarga lebih berpotensi terjadi dismenorea karena berkaitan dengan adanya faktor genetik yang menurunkan sifat kepada keturunannya. Hasil temuan di lapangan menunjukkan dari 56 responden dengan ada riwayat keluarga dismenorea terdapat $52(92,9 \%)$ responden yang mengalami dismenorea, hal ini disebabkan karena responden yang mengalami dismenorea menyatakan mempunyai saudara perempuan dan ibu yang pernah mengalami dismenorea sebelumnya. Hasil uji statistik diperoleh nilai $p$ value $=0,039<0,05$, sehingga terdapat hubungan antara riwayat keluarga dengan kejadian dismenorea pada siswi SMA Negeri 1 Lolak tahun 2021.

Adanya faktor genetik yang memperngaruhi sehingga apabila ada keluarga yang mengalami dismenore cenderung mempengaruhi psikis wanita tersebut (Charu et al., 2012). Riwayat dismenore pada keluarga lebih berpotensi terjadi dismenore karena berkaitan dengan adanya faktor genetik yang menurunkan sifat kepada keturunannya. Salah satu sifat dari 
ISSN 2623-1573 (Print)

genetik yaitu menduplikasi diri sehingga pada saat pembelahan sel, genetik akan menduplikasikan diri sehingga sifat ibu dapat menurun pada keturunannya (Sadiman, 2017).

Hasil penelitian ini sejalan dengan penelitian yang dilakukan pada remaja putri dibeberapa SMA Kabupaten Rokan Hulu dengan jumlah sampel sebanyak 80 responden (40 kelompok kasus dan 40 kelompok kontrol), menemukan ada perbedaan proporsi kejadian yang mengalami dismenorea antara responden yang ada riwayat keluarga dengan yang tidak ada riwayat keluarga (ada hubungan yang signifikan antara riwayat keluarga dengan kejadian dismenorea) (Handayani \& Rahayu, 2014). Penelitian lain yang dilakukan pada remaja putri kelas VIII SMPN 1 Gadingrejo dengan jumlah sampel sebanyak 62 responden, menemukan bahwa terdapat 25 responden yang ada riwayat keluarga $(71,4$ $\%$ ) yang mengalami dismenore dan hasil uji statistik didapatkan ada hubungan yang signifikan antara riwayat keluarga dengan kejadian dismenore dengan nilai $\mathrm{OR}=5,938$ (C1 95\% 1,967 - 17,920) (Puspita \& Wardani, 2017).

Penelitian serupa yang dilakukan pada mahasiswi Program Studi Kebidanan Metro sebanyak 106 responden (53 kelompok kasus dan 53 kelompok kontrol), menemukan ada hubungan yang bermakna antara riwayat keluarga dengan kejadian dismenorhea dengan nilai OR 18,306 (95\% CI: (6,71749.89), artinya mahasiswa yang memiliki riwayat keluarga mempunyai peluang $18 \mathrm{kali}$ mengalami dismenorhea dibandingkan siswi yang tidak ada riwayat keluarga (Sadiman, 2017). Penelitian lain yang dilakukan pada siswi kelas XI Jurusan Keperawatan SMK Sasmita Jaya 1 Pamulang dengan jumlah sampel sebanyak 60 responden, terdapat 41 responden $(68,3 \%)$ yang memiliki riyawat keluarga yang mengalami dismenorea dan hasil uji statistik menunjukkan ada hubungan riwayat keluarga yang mengalami dismenorea dengan kejadian dismenorea pada siswi ( $p$ value $=0,002<0,05)($ Romlah \& Agustin, 2021).

Riwayat faktor genetik yang terdapat pada anggota keluarga yang mengalami dismenorea sangat potensial sekali untuk menurunkan kejadian dismenorea pada anak. Hal ini disebabkan karena adanya faktor genetik yang dapat mempengaruhi keadaan responden sehingga apabila ada keluarga responden yang dismenore cenderung mempunyai pengaruh psikis dismenorea. Menurut (Sadiman, 2017) pencegahan untuk mengatasi dismenorea terutama bagi yang memiliki riwayat dismenorea pada keluarga dengan pemenuhan gizi yang seimbang, kurangi konsumsi makanan dan minuman yang mengandung kafein, hidup yang sehat, mengurangi stres atau keluhan psikologi, dan melakukan aktivitas fisik atau berolah raga.

\section{Hubungan Kebiasaan Olahraga dengan Kejadiam Dismenorea pada Siswi}

Kebiasaan olahraga merupakan salah satu bentuk aktivtas fisik yang dilakukan secara teratur. WHO mendefinisikan aktivitas fisik sebagai semua bentuk gerakan tubuh yang memerlukan pengeluaran energi dan pembakaran kalori. Aktivitas fisik adalah gerakan tubuh yang meningkatkan pengeluaran tenaga atau energi dan juga pembakaran energi. Aktivitas fisik dikategorikan cukup apabila seseorang melakukan latihan fisik atau olahraga minimal 30 menit selama 3-5 kali dalam seminggu (Kemenkes RI, 2013).

Kejadian dismenorea akan meningkat pada wanita yang kurang atau jarang melakukan aktivitas fisik olahraga apalagi tidak pernah sama sekali melakukan olahraga. Hasil temuan dilapangan menunjukkan dari 57 responden yang jarang melakukan olahraga terdapat 53 (93\%) responden yang mengalami dismenorea, hal ini dapat disebabkan oleh responden yang 
kurang olahraga akan menyebabkan oksigen tidak dapat tersalurkan dengan baik pada pembuluh-pembuluh darah dibagian reproduksi yang pada saat itu terjadi vasokontriksi sehingga responden mengalami nyeri haid. Hasil uji statistik diperoleh $p$ value $=0,024<0,05$, sehingga ada hubungan yang antara kebiasaan olahraga dengan kejadian dismenorea pada siswi SMA Negeri 1 Lolak tahun 2021.

Hasil penelitian ini sejalan dengan penelitian yang dilakukan pada siswi SMAN 04 Banda Aceh dengan jumlah sampel sebanyak 75 orang, menemukan bahwa ada hubungan yang signifikan antara olahraga dengan kejadian dismenore primer $(\mathrm{p}$ value $=$ $0,043<0,05)$. Siswi yang dismenorea menyatakan mereka minum obat untuk mengatasi dismenore primer dibandingkan melakukan olahraga secara teratur untuk mengatasi nyeri haid (Fithriany \& Amelia, 2015). Penelitian lain yang dilakukan pada siswi SMAN 15 Semarang dengan jumlah sampel sebanyak 138 responden, menemukan bahwa ada hubungan yang signifikan antara kebiasaan olahraga dengan dismenore primer pada siswi dengan nilai $p$ value 0,000 . Terdapat 9 responden yang mengalami dismenorea meskipun mempunyai kebiasaan olahraga dalam kategori sering hal ini disebabkan karena kejadian dismenorea dapat disebabkan oleh multifaktor diantaranya usia menarche, stress, status gizi, riwayat keluarga, merokok, dan faktor psikologi (Rohmawati \& Wulandari, 2019).

Penelitian serupa yang dilakukan pada siswi kelas X SMA Negeri 78 Jakarta Barat dengan jumlah sampel sebanyak 168 responden pada masing-masing kelompok kontrol dan kasus sebanyak 84, menemukan bahwa kebiasaan olahraga terbukti berpengaruh terhadap kejadian dismenor primer p-value 0,043 OR 1,937 (95\% CI: 1,021-3,672) (Temesvari et al., 2019). Penelitian lain yang dilakukan pada remaja putri SMA Pemuda Banjaran dengan jumlah sampel sebanyak 117 responden, menemukan bahwa terdapat hubungan yang signifikan antara kebiasaan olahraga dengan kejadian dismenore primer dengan nilai $p$ value 0,03 (Hayati \& Agustin, 2020).

Kebiasaan olahraga berpengaruh signifikan terhadap kejadian dismenorea pada remaja putri, banyak remaja putri mengabaikan kebiasaan olahraga untuk mencegah terjadinya dismenorea. Aktivitas olahraga yang rutin dapat dilakukan diantaranya jalan santai, lari cepat, bersepeda, berenang, zumba, aerobik dan jogging. Aktivitas olahraga yang jarang dilakukan remaja putri mengakibatkan sirkulasi udara dan oksigen menjadi tidak lancar sehingga supply oksigen ke pembuluh darah di organ reproduksi juga menjadi kurang. Gejala dismenorea dapat diminimalisir dengan berolahraga karena pada saat melakukan aktivitas olahraga terjadi pelepasan endorphin pada sirkulasi pembuluh darah yang lancar.

\section{KESIMPULAN}

Berdasarkan hasil penelitian dapat disimpulkan bahwa faktor-faktor yang berhubungan dengan kejadian dismenorea pada siswi SMA Negeri 1 Lolak adalah usia menarche, riwayat keluarga dan kebiasaan olahraga. Faktor diatas adalah merupakan penyebab tidak langsung kejadian dismenorea pada remaja putri sehingga faktor tersebut dapat dimodifikasi dengan melakukan tindakan pencegahan untuk meminimalisir kejadian dismenorea pada remaja putri.

\section{UCAPAN TERIMAKASIH}

Ucapan terima kasih peneliti haturkan kepada Ketua Yayasan Bogani yang telah memberikan dukungan sehingga penelitian ini bisa terlaksana dengan baik. Kepada Rektor dan Ketua LPPM Institut Kesehatan 
ISSN 2623-1573 (Print)

dan Teknologi Graha Medika yang telah memberikan motivasi dan dukungan moral kepada peneliti dalam pelaksanaan penelitian. Kepada Kepala SMA Negeri 1 Lolak yang telah memberikan izin pelaksanaan penelitian dan terima kasih kepada seluruh responden (siswi) yang telah ikut berpartisipasi dalam penelitian ini.

\section{DAFTAR PUSTAKA}

Adriani, P. (2018). Hubungan Body Mass Index (BMI) Dengan Dismenorea Primer Di SLTP Negeri 2 Kemangkon Kabupaten Purbalingga. Bidan Prada: Jurnal Publikasi Kebidanan Akbid YLPP Purwokerto, 9(2).

Ammar, U. R. (2016). Faktor risiko Dismenore primer pada wanita usia subur di Kelurahan Ploso Kecamatan Tambaksari Surabaya. Jurnal Berkala Epidemiologi, 4(1), 37-49.

Anwar, C., \& Rosdiana, E. (2019). Hubungan Indeks Masa Tubuh dan Usia Menarche dengan Kejadian Dismenorea pada Remaja Putri di SMA Negeri 1 Samudera tahun 2015. Journal of Healthcare Technology and Medicine, 2(2), 144-153.

BPS Sulut. (2017). Data Penduduk Remaja di Sulawesi Utara. Badan Pusat Statistik Sulawesi Utara. https://manadokota.bps.go.id/statictable/ 2017/08/18/198/jumlah-penduduk-kotamanado-menurut-kelompok-umur2011-2016.html

Charu, S., Amita, R., Sujoy, R., \& Thomas, G. A. (2012). Menstrual characteristics and Prevalence and Eff ect of Dysmenorrhea on Quality of Life of medical student s. International Journal of Collaborative Research on Internal Medicine \& Public Health, 4(4), 0.

Fithriany, F., \& Amelia, U. (2015). Hubungan Kebiasaan Olahraga dengan Dismenore Primer pada Remaja Putri di SMA Negeri 04 Banda Aceh Tahun
2014. Jurnal Ilmiah PANNMED (Pharmacist, Analyst, Nurse, Nutrition, Midwivery, Environment, Dentist), 10(1), 121-124.

Handayani, E. Y., \& Rahayu, L. S. (2014). Faktor-Faktor Yang Berhubungan Dengan Nyeri Menstruasi (Dismenorea) Pada Remaja Putri di Beberapa SMA di Kabupaten Rokan Hulu. Jurnal Martenity and Neonatal, 1(4), 161-171.

Hayati, S., \& Agustin, S. (2020). FaktorFaktor Yang Berhubungan Dengan Dismenore Pada Remaja Di SMA Pemuda Banjaran Bandung. Jurnal Keperawatan BSI, 8(1), 132-142.

Jayanti, C. (2021). Hubungan Status Gizi dan Usia Menarche dengan Kejadian Dismenore pada Mahasiswa Tingkat I Semester II Akademi Kebidanan RSPAD Gatot Soebroto. Jurnal Bidan Komunitas, 4(2), 89-95.

Kusmindarti, I., \& Munadlifah, S. (2016). Hubungan Kebiasaan Olahraga dengan Kejadian Dismenorea pada Remaja Putri di Komunitas Senam Aerobik Dr Tri Widodo Basuki Jabon Mojoanyar Mojokerto. Jurnal Kebidanan, 5(1), 2732.

Lail, N. H. (2019). Hubungan Status Gizi, Usia Menarche dengan Dismenorea pada Remaja Putri di SMK K Tahun 2017. Jurnal Ilmiah Kebidanan Indonesia, 9(02), 88-95.

Larasati, T. A., \& Alatas, F. (2016). Dismenore primer dan faktor risiko Dismenore primer pada Remaja. Jurnal Majority, 5(3), 79-84.

Nirwana, A. . (2011). Psikologi Kesehatan Wanita (Remaja, Menstruasi, Menikah, Hamil, Nifas, Menyusui). Yogyakarta: Nuha Medika.

Payitno, S. (2014). Buku Lengkap Kesehatan Organ Reproduksi Wanita. Yogyakarta: Saufa.

Ponda, A., \& Belung, C. O. (2018). Hubungan Pengetahuan Remaja Tentang 
Dysmenorea Saat Menstruasi Dengan Mekanisme Koping Saat Dismenorea Pada Siswi Kelas VIII SMP Kristen Tawaang Minahasa Selatan. Journal Of Community Dan Emergency, 6(2).

Prawiroharjo, S. (2020). Ilmu Kebidanan

Sarwono Prawirohardjo, Edisi 4. Jakarta: PT Bina Pustaka.

Puspita, L., \& Wardani, P. K. (2017). Hubungan usia pertama menstruasi (menarche) dan riwayat keluarga dengan kejadian dismenore pada remaja putri kelas VIII di SMPN I Gadingrejo Kecamatan Gadingrejo Kab. Pringsewu tahun 2016. Jurnal Kelitbangan Bappeda Pringsewu, 2(1), 1-16.

Rohmawati, W., \& Wulandari, D. A. (2019).

Faktor yang Berhubungan dengan Nyeri Dismenore Primer pada Siswi di SMA Negeri 15 Semarang. Jurnal Bidan Cerdas, 1(3), 129-136.

Romlah, S. N., \& Agustin, M. M. (2021). Faktor-Faktor yang Berhubungan dengan Kejadian Dismenorea pada Siswa Kelas XI Jurusan Keperawatan di SMK Sasmita Jaya 1 Pamulang. PROSIDING SENANTIAS: Seminar Nasional Hasil Penelitian Dan Pengabdian Kepada Masyarakat, 1(1), 383-392.

Sadiman, S. (2017). Analisis Faktor yang Berhubungan dengan Kejadian Dismenorhea. Jurnal Kesehatan, 8(1), 41-49.

Sakinah, \& Ekayanti, I. (2016). No TitleFaktor-Faktor Yang Behubungan Dengan Kejadian Dismenorea Primer Pada Remaja. https://repository.ipb.ac.id/handle/1234 $56789 / 86954$

Soesilowati, R., \& Annisa, Y. (2017). Pengaruh usia menarche terhadap terjadinya disminore primer pada siswi mts maarif NU al hidayah Banyumas. Medisains, 14(3).

Sugiyono. (2017). Metode Penelitian Kuantitatif, Kualitatif, dan $R \& D$. Bandung: Alfabeta CV.

Sukarni, I., \& Margareth. (2013). Kehamilan, Persalinan, Nifas di lengkapi Patologi. Yogyakarta: Nuha Medika.

Susanti, A. V., \& Sunarto, S. (2012). Faktor Risiko Kejadian Menarche Dini pada Remaja di SMP N 30 Semarang. Jurnal Of Nutrition College, 1(1), 115-126.

Syafriani. (2021). Hubungan Status Gizi dan Umur Menarche dengan Kejadian Dismenore pada Remaja Putri di SMAN 2 Bangkinang Kota 2020. Jurnal Ners, 5(1), 32-37.

Tavallaee, M., Joffres, M. R., Corber, S. J., Bayanzadeh, M., \& Rad, M. M. (2011). The prevalence of menstrual pain and associated risk factors among Iranian women. Journal of Obstetrics and Gynaecology Research, 37(5), 442-451.

Temesvari, N. A., Adriani, L., \& Qomarania, W. Z. (2019). Efek Olahraga terhadap Kejadian Dismenor Primer pada Siswi Kelas X SMA Negeri 78 Jakarta Barat. Media Kesehatan Masyarakat Indonesia, 15(3), 213-219.

Utami, A. N. R., Ansar, J., \& Sidik, D. (2013). Faktor yang berhubungan dengan kejadian dismenore pada remaja putri di sman 1 kahu kabupaten bone. Tugas Akhir. Tidak Diterbitkan, Bagian Epidemiologi FKM UNHAS.

Wulanda, C., Luthfi, A., \& Hidayat, R. (2020). Efektifitas Senam Dismenore Pada Pagi Dan Sore Hari Terhadap Penanganan Nyeri Haid Pada Remaja Putri Saat Haid di SMPN 2 Bangkinang Kota Tahun 2019. Jurnal Kesehatan Tambusai, 1(1), 1-11. 